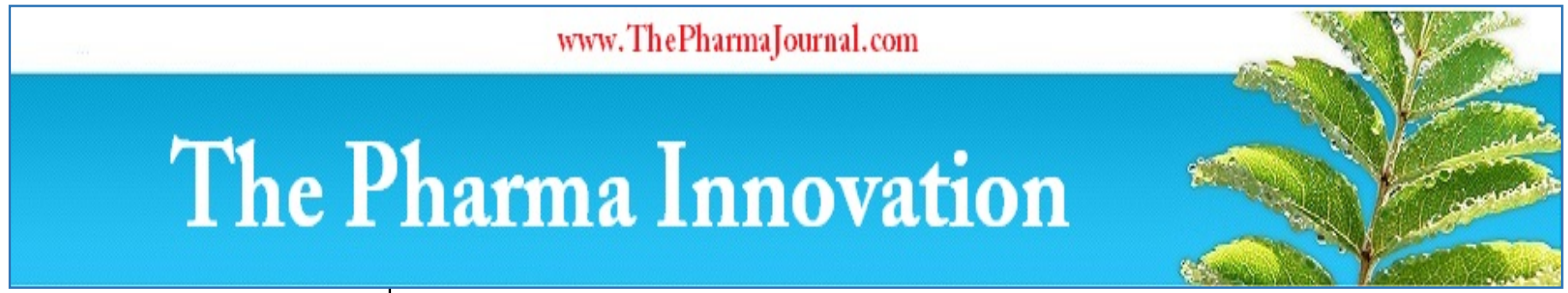

ISSN (E): 2277 - 7695

ISSN (P): 2349-8242

NAAS Rating: $\mathbf{5 . 2 3}$

TPI 2021; 10(10): 47-53

(C) 2021 TPI

www.thepharmajournal.com

Received: 07-08-2021

Accepted: 16-09-2021

Abarna Ravichandran

PG Scholar, Department of

Agricultural Microbiology,

TNAU, Coimbatore, Tamil

Nadu, India

Kalaiselvi Thangavel

Professor, Department of

Agricultural Microbiology,

TNAU, Coimbatore,

Tamil Nadu, India

Anandham Rangasamy Assistant Professor, Department of Agricultural Microbiology,

TNAU, Coimbatore,

Tamil Nadu, India
Corresponding Author: Kalaiselvi Thangavel

Professor, Department of Agricultural Microbiology,

TNAU, Coimbatore,

Tamil Nadu, India

\section{Maize spermosphere bacterial endophytes and their biotic and abiotic stress tolerance traits}

\author{
Abarna Ravichandran, Kalaiselvi Thangavel and Anandham Rangasamy
}

DOI: https://doi.org/10.22271/tpi.2021.v10.i10a.8332

\begin{abstract}
In the present study, 12 bacterial endophytes (C1 to C12) were isolated from three different genotypes of maize seed (COH6). Seed endophytes are considered as pioneers of plant microbiome and enhance the plant defense response at an early stage of crop growth and later stages of seedling development. The seed-associated endophytes exhibit the antagonistic property against the fungal pathogen (Fusarium oxysporum and Macrophomina phaseolina) of maize. Among 12 isolates, C11 suppressed the mycelial growth of both the tested pathogens. Furthermore, the selected isolates were subjected to in vitro abiotic stress tolerance such as salt, drought and temperature stress. The isolates C3, C5, C7, and C12 showed increased tolerance to drought, salt and temperature stress and might assist the host plant in alleviating the ill-effects of abiotic stress on maize. On a whole, microbial isolates associated with the seeds could be a better candidate in biotic and abiotic stress tolerance and would develop those isolates as consortia for obtaining desirable growth in maize.
\end{abstract}

Keywords: Biochemical characteristics, maize, seed endophytes, stress tolerance

\section{Introduction}

Stress is one of the major agricultural constraints that limit crop yield, health, and productivity [1]. Biotic and abiotic stress upon plants is mainly responsible for the disruption of plant equilibrium having deleterious effects on plant health and functioning. The predominance of biotic stress such as pathogen, pest, and abiotic stress such as salt, drought, and high temperature negatively impact crop growth and functioning. Microbial inoculants have been recognized as beneficial and eco-friendly ones that can enhance host response to withstand biotic and abiotic stress.

The bacterial endophytes are symbionts present everywhere in plant species without harming the host, known to improve plant growth and development. They exhibit ecological benefits to plant fitness which can be used for sustainable agricultural production. The seeds serve as a vehicle for the transmission of endophytes passed on to successive generations (vertical transmission). Though, seed endophytes are unexploited source now it is emerging as a potential source of microbial inoculants ${ }^{[2]}$. From a native pool of microorganisms, beneficial microbes are likely to colonize the seeds, establishes an initial microflora and support the host plant in every phase of seedling development.

Maize is an important cereal crop and is called as Queen of cereals, widely cultivated throughout the world. Maize is one of the major energy-providing crops for more than half of the population after rice and wheat ${ }^{[3]}$. It is being cultivated throughout the world and contributes around one-fourth of global cereal grain production. However, the production and yield of maize were influenced by both biotic and abiotic stress. To mitigate these factors microbial-based remediation is to be taken which enhances the survival ability of plants and helps in sustaining the crop yield. The endophytes isolated from the maize seeds would be an efficient inoculum that can act as an initial colonizer and recruits the indigenous microbes and participates in stress alleviation ${ }^{[4]}$.

Therefore, the present study aims in identifying the bacterial endophytes associated with seeds isolated from three different genotypes (Male, female, and hybrid) of maize and screening of isolates for their potential to withstand the abiotic stress such as drought, temperature, and salt and also for their antagonistic property against the seed-borne pathogen. 


\section{Materials and Methods}

2.1 Seed sample collection and isolation of endophytes The fresh seeds of three different genotypes (male, female, and hybrid) of maize (COH6) were obtained from the Department of Millets, TNAU, Coimbatore. For isolation of seed bacterial endophytes, the collected seeds were surface sterilized using 4\% sodium hypochlorite for $2 \mathrm{~min}$, followed by $70 \%$ ethanol for $2-3 \mathrm{~min}$ and finally rinsed with sterile double distilled water to eliminate the epiphytes and other undesirable microorganisms under aseptic condition. The surface-sterilized seeds were macerated using phosphate buffer saline in a sterile pestle and mortar. From the macerated wash, $1 \mathrm{~mL}$ was used to make serial dilutions up to $\left(10^{-4}\right)$ plated on six different media such as Tryptic soy agar (TSA), Nutrient agar (NA), Luria Bertani (LB), Soil extract agar (SEA), Reasoner's 2A agar (R2A) and Starch casein agar (SCA). The plates were incubated at $28 \pm 2^{\circ} \mathrm{C}$ for $24-48 \mathrm{~h}$. At the end of the incubation period, the plates were observed for the appearance of bacterial colonies ${ }^{[5]}$. The morphologically different colonies were picked and purified by repeated streaking onto a respected media and the purified isolates were stored in $60 \%$ glycerol and kept at $-80^{\circ} \mathrm{C}$.

\subsection{Morphological identification of bacteria}

Bacterial colonies formed on each media were characterized morphologically by observing the traits such as shape, size, elevation, form, color, edge, and appearance. According to the morphological observations, 12 different bacterial colonies were picked and screened for biochemical and biotic \& abiotic stress tolerance.

\subsection{Biochemical characterization of selected bacterial endophytes}

The bacterial endophytes were screened for biochemical characterization namely indole production test, catalase test as per the protocol [6], methyl red and Voges Proskauer test ${ }^{[7]}$, citrate utilization test, $\mathrm{KOH}$ test [8], Gram staining [9], Cellulase, Pectinase, and Amylase test ${ }^{[10-12]}$.

\subsection{Screening of endophytes for antagonistic activity}

The antagonistic activity of selected twelve bacterial endophytes was assessed against major fungal plant pathogens of maize namely Macrophomina phaseolina and Fusarium oxysporum by dual culture method ${ }^{[13]} .5 \mathrm{~mm}$ of a fungal disc of actively grown Macrophomina phaseolina and Fusarium oxysporum were placed on PDA plates. The test bacterial isolates were cross-streaked at the other edge of the plate $3 \mathrm{~cm}$ away from the fungal disc. The fungal disc without bacterial streak was maintained as a control plate and the plates were sealed with parafilm and incubated at $27 \pm 2{ }^{\circ} \mathrm{C}$ for 5 days until the fungal growth covers the edge of the control. The mycelial growth inhibition by the bacterial isolates shows the antagonistic activity and percent inhibition was calculated.

Percentage of inhibition $=\frac{\mathrm{C}-\mathrm{T}}{C}$

C - Radial mycelial growth of the pathogen in the control plate

$\mathrm{T}$ - Radial mycelial growth of the pathogen in bacterial isolates-streaked plate

\subsection{Screening of bacterial endophytes for abiotic stress tolerance}

The twelve selected bacterial endophytes were tested for their different abiotic stress tolerance. The bacterial endophytes were grown under different abiotic stresses such as salt (1\%, $3 \%$ and $5 \% \mathrm{NaCl})$, moisture stress $(-1 \mathrm{MPa},-2 \mathrm{MPa}$ and $3 \mathrm{MPa})$ PEG concentration and temperature $\left(4^{\circ} \mathrm{C}\right.$ and $\left.50^{\circ} \mathrm{C}\right)$ [14]. The growth of each bacterial endophyte was recorded at different time intervals and their absorbance was measured at $600 \mathrm{~nm}$.

\subsection{Salt tolerance}

$0.1 \mathrm{~mL}$ of each bacterial endophyte was inoculated into different test tubes containing $10 \mathrm{~mL}$ of tryptic soy broth (TSB) supplemented with different salt concentrations (1\%, $3 \%$, and $5 \%(\mathrm{w} / \mathrm{v}))$. The test tubes were incubated at $28^{\circ} \mathrm{C}$ and the growth was recorded. The bacterial cell growth was measured using a spectrophotometer at an optical density of OD 600nm.

\subsection{Moisture stress tolerance}

To determine the moisture stress tolerance by the bacterial isolates, $0.1 \mathrm{~mL}$ of bacterial suspension was poured into TSB broth amended with different concentrations of PEG 6000 ($1 \mathrm{MPa}$, -2MPa, and -3MPa). The uninoculated were maintained as control. The inoculated tubes were incubated at $28^{\circ} \mathrm{C}$ and the growth was recorded. The bacterial cell growth was measured using a spectrophotometer at an optical density of OD 600nm.

\subsection{Temperature tolerance}

The temperature tolerance of selected bacterial isolates was tested at $4^{\circ} \mathrm{C}$ (low temperature) and $50^{\circ} \mathrm{C}$ (high temperature). $10 \mathrm{~mL}$ of tryptic soy broth dispensed with $0.1 \mathrm{~mL}$ of bacterial suspension and the tubes were incubated at $4^{\circ} \mathrm{C}$ and $50^{\circ} \mathrm{C}$ and the growth of cells were recorded. The bacterial cell growth was measured using a spectrophotometer at an optical density of OD 600nm.

\section{Statistical Analysis}

All the experiments were carried out with triplicates by applying a completely randomized block design and analyzed by standard analysis of variance (one-way ANOVA). The treatment mean was compared by Duncan multiple range test (DMRT) at $p<0.05$ using SPSS 16.0 software.

\section{Result and Discussion}

\subsection{Isolation of bacteria and total viable count}

The fresh seeds of three different maize seeds were collected and surface sterilized using 4\% sodium hypochlorite and $70 \%$ ethanol as mentioned in materials and methods. The seeds were macerated, serially diluted up to $10^{4}$, and plated on six different media, and colonies were purified by repeated streaking on respective medium. The endophytic bacterial population of maize seeds was shown in Table 1. Among the six different media used, the highest bacterial count of 5.5 $\mathrm{x} 10^{5} \mathrm{cfu}$ 's/g of seed on NA followed by $2.3 \times 10^{5}$ on LB, 7.0 $\mathrm{x} 10^{5}$ on TSA was observed and the count was gradually reduced in SEA, R2A, and SCA. The viable count of male seed was recorded the highest on NA with a value of $4.0 \times 10^{4}$ followed by $3.3 \times 10^{4}$ on LB and $3.1 \times 10^{4}$ on TSA. On accounting for the population of female seeds of maize, the highest population count of $1.4 \times 10^{4}$ was observed on TSA followed by $1.2 \times 10^{4}$ on LB while on the SEA and SCA, no growth was observed for both male and female seeds.

Plants living in a natural habitat have to confront diverse stress factors. Many scientific reports have revealed the benefits of endophytic microbes in enhancing the growth potential of crops under various stress conditions. On a morphological basis, 12 isolates were selected, purified, 
screened for their biotic and abiotic stress tolerance, and pure isolates were maintained in TSA slants for future works (Table 2) ${ }^{[15]}$. Reported that most of the endophytes isolated from the maize seeds show- antagonistic activity against phytopathogens and could withstand inanimate stress conditions.

\subsection{Characterization of selected endophytes}

The biochemical characteristics and carbohydrate utilization test of twelve selected bacterial endophytes of maize seed are shown in Table 3. The twelve endophytes were characterized morphologically and biochemically. Among 12 endophytes, 4 endophytes were found to be gram-negative and the remaining 8 endophytes were gram-positive. None of the isolates showed positive for indole production whereas 7 isolates showed positive for methyl red production and 5 isolates showed positive for Voges-Proskauer test. Almost all the 12 isolates utilized all the sugars (Table 3). Out of 12, only 5 isolates showed positive for citrate utilization, 4 isolates showed positive for amylase production and 8 isolates showed positive for cellulase production.

\subsection{Antagonistic assay}

To screen the antagonistic activity of bacterial endophytes s, in vitro dual culture plate assay was used. Out of 12 bacterial endophytes, 9 isolates (C1, C2, C3, C4, C6, C7, C9, C11, and C12) were able to inhibit the growth of Fusarium oxysporum whereas the Macrophomina phaseolina growth was arrested by only one isolate C11 (Table 5). C11 was able to inhibit the growth of both Fusarium oxysporum and Macrophomina phaseolina as shown in figure $4^{[2]}$. Reported that seedassociated bacterial endophytes of cultivated cucurbits have significant antagonistic activity against major fungal plant pathogens (Fusarium graminearum, Rhizoctonia solani, Pythium aphanidermatum, and Phytophthora capsici).

\subsection{Salinity tolerance}

The seed bacterial endophytes are known to be subjected to different abiotic stresses. As they could sustain in such environments, it could complement the plants in stress alleviation ${ }^{[14]}$. The endophytes enhance the adaptation ability of plants and protect the crops from stresses such as high temperature, drought, salinity, and other harsh environmental conditions ${ }^{[16]}$. Many workers ${ }^{[15]}$ reported the maize seedassociated endophytic bacterial isolates could tolerate the different concentrations of salinity up to $10 \%$.
The salinity tolerance of all the bacterial isolates was evaluated using TSB with different $\mathrm{NaCl}$ concentrations (1\%, $3 \%$, and 5\%) and the results are shown in Table 4 \& Figure 1. At high salt concentration, C12 showed maximum growth followed by C8, C5, and C1, which showed prominent growth. Almost all the bacterial isolates showed increased growth in $1 \% \mathrm{NaCl}$ and the growth of all the endophytes reduced gradually in $3 \%$ and $5 \% \mathrm{NaCl}$. The endophytes of peanuts have also been reported to alleviate the salinity stress and enhance the plant yield ${ }^{[17]}$.

\subsection{Moisture stress tolerance}

A total of 12 isolates were subjected to different PEG 6000 concentrations (-1MPa, -2MPa, and -3MPa) and the absorbance was measured at $600 \mathrm{~nm}$. The results revealed that all the 12 endophytes could tolerate moisture stress of $1.0 \mathrm{MPa}$ and thereafter the growth of endophytes declined gradually with an increase in PEG 6000 concentration (Table 5 and Figure 2). Out of 12 isolates, C7 showed prominent growth under all 3-water potential ${ }^{[18]}$. Reported that Kosakonia cowanii endophytic bacteria isolated from a xerophytic invasive plant, Lactuca serriola possess the drought-tolerant ability and promoted the growth of Arabidopsis thaliana.

\subsection{Temperature tolerance}

Temperature is one of the prominent factors which is evident for the growth of bacterial communities under extreme environmental niches ${ }^{[19]}$. Based on the temperature limits, the endophytes were tested for their growth at $4^{\circ} \mathrm{C}$ (lower temperature) and high temperature $\left(40^{\circ} \mathrm{C}\right.$ and $\left.50^{\circ} \mathrm{C}\right)$ at different time intervals $(0,24,48 \mathrm{~h})$, respectively (Table 3$)$. All the 12 isolates showed enhanced growth at $40^{\circ} \mathrm{C}$, while a decrease in growth was observed at $50^{\circ} \mathrm{C}$, and growth of the isolates was negligible at $4^{\circ} \mathrm{C}$ (Figure 3 ). Out of 12 isolates, $\mathrm{C} 2, \mathrm{C} 3$, and C8 showed increased growth at $50^{\circ} \mathrm{C}$ among those, $\mathrm{C} 2$ was found to be better stress-tolerant. On the other hand, C5 showed better growth at $4^{\circ} \mathrm{C}$. To ameliorate the impact of heat stress, endophytic bacteria with plant growthpromoting activity is an effective and eco-friendly approach that could be used for economically significant crops worldwide. Many of the reports suggest that the use of the plant endophytic bacteria aids in improving the stress tolerance and protect the plants from adverse environmental conditions.

Table 1: Endophytic bacterial flora of Maize hybrid COH6, parental line (Male), parental line (Female)

\begin{tabular}{|c|c|c|c|c|c|c|}
\hline \multirow{2}{*}{$\begin{array}{l}\text { Name of the } \\
\text { Sample }\end{array}$} & \multirow{2}{*}{ Medium used } & \multicolumn{4}{|c|}{ Colony morphology } & \multirow{2}{*}{$\begin{array}{c}\text { Population } \\
\text { (cfu/g of seed) }\end{array}$} \\
\hline & & Color & Elevation \& Edge & Size & Form & \\
\hline \multirow{6}{*}{$\begin{array}{l}\text { Maize COH6 } \\
\text { (Hybrid seed) }\end{array}$} & NA & White & Translucent, flat & Small & Irregular & $5.5 \times 10^{5}$ \\
\hline & LB & Pale white & Convex, entire & Small & Irregular & $2.3 \times 10^{5}$ \\
\hline & TSA & White & Entire, Opaque & Small & Circular & $7.0 \times 10^{4}$ \\
\hline & SEA & White & Flat, entire & Small & Circular & $10.0 \times 10^{3}$ \\
\hline & R2A & White & Convex, entire & Small & Circular & $2.0 \times 10^{3}$ \\
\hline & SCA & White & Convex, flat, Pinpointed & Small & Circular & $2.0 \times 10^{3}$ \\
\hline \multirow{4}{*}{$\begin{array}{c}\text { Maize UMI- } \\
1230 \text { (Male seed) }\end{array}$} & NA & Pale white & Raised, entire & Small & Circular & $4.0 \times 10^{4}$ \\
\hline & LB & White & Raised, entire & Medium & Circular & $3.3 \times 10^{4}$ \\
\hline & TSA & Pale white & Raised, opaque & Small & Irregular & $3.1 \times 10^{4}$ \\
\hline & R2A & Creamy white & Raised, opaque & Large & Circular & $9.0 \times 10^{3}$ \\
\hline \multirow{4}{*}{$\begin{array}{c}\text { Maize UMI-1200 } \\
\text { (Female seed) }\end{array}$} & NA & Pale white & Flat, misty, entire & Small & Circular & $12.0 \times 10^{3}$ \\
\hline & LB & Pale white & Raised, entire & Small & Circular & $5.0 \times 10^{3}$ \\
\hline & TSA & White & Raised, entire & Medium & Irregular & $14.0 \times 10^{3}$ \\
\hline & R2A & Pale white & Raised, Opaque & Small & Circular & $11.0 \times 10^{3}$ \\
\hline
\end{tabular}


Table 2: Dominant and unique endophytic bacterial flora of male, female and hybrid of Maize COH6

\begin{tabular}{|c|c|c|c|}
\hline Isolate & Source & Morphological characteristics & $\begin{array}{c}\text { Gram's reaction } \\
\text { characteristics }\end{array}$ \\
\hline C1 & Male-LB & Thick, golden pinpoints, raised colonies & - \\
\hline C2 & Male-LB & Thin, slight creamy yellow with white pinpoints & + \\
\hline C3 & Male-LB & Yellow color, thin, slightly raised colonies & + \\
\hline C4 & Female-TSA & Thick, creamy yellow, polysaccharides producing colonies & + \\
\hline C5 & Female-TSA & Thick, exopolysaccharide producing, slight light yellow creamy & + \\
\hline C6 & Female-TSA & Dry, moderate thickness, slight reddish tinge color colonies & + \\
\hline C7 & Male-TSA & Dry, thick, white creamy, slightly raised colonies & + \\
\hline C8 & Female-NA & Moderate thick, white creamy, exopolysachharide producing colonies & + \\
\hline C9 & Female-NA & Moderate thick, white colony at edge, slight yellow color, exopolysaccharide producing colonies & \\
\hline C10 & Male-NA & Thin, small, pale white, creamy, exopolysaccharide producing & + \\
\hline C11 & Hybrid-R2A & Large, pale white yellow creamy color colonies & - \\
\hline C12 & Hybrid-R2A & Thin. Slight yellow creamy colony with cloudy appearance & - \\
\hline
\end{tabular}

Note: + and - sign indicates the positive and negative for gram staining

Table 3: Biochemical characteristics of selected endophytes

\begin{tabular}{|c|c|c|c|c|c|c|c|c|c|}
\hline Isolates & IP test & MR test & VP test & CUT test & KOH test & Catalase test & Amylase test & CMC test & Pectinase test \\
\hline C1 & - & - & + & + & + & - & - & - & - \\
\hline C2 & - & - & + & - & - & - & + & + & - \\
\hline C3 & - & - & + & - & - & - & + & + & + \\
\hline C4 & - & + & - & - & - & - & - & - & - \\
\hline C5 & - & - & + & + & - & - & - & - & - \\
\hline C6 & - & + & - & - & - & - & - & + & + \\
\hline C7 & - & + & - & - & - & - & + & + & + \\
\hline C8 & - & - & + & + & - & - & - & - & + \\
\hline C9 & - & + & - & - & - & - & + & + & - \\
\hline C10 & - & + & - & - & + & - & - & + & - \\
\hline C11 & - & + & - & + & + & + & - & + & + \\
\hline C12 & - & + & - & + & + & + & - & + & + \\
\hline
\end{tabular}

Note: + and - negative sign indicates the positive and negative results for biochemical test

IP- Indole Production, MR- Methyl red, VP - Vogus-Proskauer, CUT- Citrate Utilization test

Table 4: Growth of the bacterial isolates under different abiotic stress measured in terms of absorbance 600nm

\begin{tabular}{|c|c|c|c|c|c|c|c|c|c|c|}
\hline \multirow{2}{*}{ Isolates } & \multirow{2}{*}{ Non-Stressed } & \multicolumn{3}{|c|}{ Salt stress (NaCl) } & \multicolumn{3}{|c|}{ Moisture stress (PEG) } & \multicolumn{3}{|c|}{ Temperature stress $\left({ }^{\circ} \mathrm{C}\right)$} \\
\hline & & $1 \%$ & $3 \%$ & $5 \%$ & $-1 \mathrm{MPa}$ & $-2 \mathrm{MPa}$ & -3 Мра & $4^{\circ} \mathrm{C}$ & $40^{\circ} \mathrm{C}$ & $50^{\circ} \mathrm{C}$ \\
\hline $\mathrm{C} 1$ & $1.025^{\mathrm{h}}$ & $1.618^{\mathrm{c}}$ & $1.499^{\mathrm{a}}$ & $0.916^{\mathrm{c}}$ & $0.622^{\mathrm{ab}}$ & $0.13^{\mathrm{fg}}$ & $0.061^{\mathrm{f}}$ & $0.178^{\mathrm{b}}$ & $2.201^{\mathrm{a}}$ & $0.113^{\mathrm{g}}$ \\
\hline $\mathrm{C} 2$ & $1.043^{\mathrm{gh}}$ & $0.726^{f}$ & $0.567^{\mathrm{e}}$ & $0.557^{\mathrm{e}}$ & $0.647^{\mathrm{a}}$ & $0.128^{\mathrm{fg}}$ & $0.057^{\mathrm{f}}$ & $0.071^{\mathrm{h}}$ & $1.876^{\mathrm{c}}$ & $0.917^{\mathrm{a}}$ \\
\hline C3 & $1.149^{\mathrm{ef}}$ & $0.621^{\mathrm{g}}$ & $0.350^{\mathrm{f}}$ & $0.242^{g}$ & $0.439^{\mathrm{fg}}$ & $0.471^{\mathrm{b}}$ & $0.164^{\mathrm{c}}$ & $0.073^{\mathrm{h}}$ & $0.694^{\mathrm{h}}$ & $0.719^{\mathrm{b}}$ \\
\hline $\mathrm{C} 4$ & $1.177^{\text {def }}$ & $0.527^{\text {gh }}$ & $0.297^{\mathrm{f}}$ & $0.254^{\mathrm{g}}$ & $0.546^{\mathrm{cd}}$ & $0.209^{\mathrm{e}}$ & $0.08^{\mathrm{e}}$ & $0.106^{\mathrm{ef}}$ & $1.026^{\mathrm{g}}$ & $0.309^{\mathrm{d}}$ \\
\hline C5 & $1.275^{\mathrm{bcd}}$ & $1.440^{\mathrm{d}}$ & $1.048^{\mathrm{c}}$ & $0.898^{\mathrm{c}}$ & $0.533^{\text {de }}$ & $0.112^{\text {gh }}$ & $0.041^{\mathrm{g}}$ & $0.386^{\mathrm{a}}$ & $2.118^{\mathrm{ab}}$ & $0.117^{\mathrm{fg}}$ \\
\hline C6 & $1.128^{\mathrm{fg}}$ & $0.315^{\mathrm{i}}$ & $0.29^{f}$ & $0.162^{\mathrm{h}}$ & $0.506^{\mathrm{de}}$ & $0.085^{\mathrm{h}}$ & $0.039^{g}$ & $0.086^{\text {gh }}$ & $1.494^{\mathrm{e}}$ & $0.164^{\mathrm{e}}$ \\
\hline C7 & $1.793^{\mathrm{a}}$ & $0.345^{\mathrm{i}}$ & $0.339^{\mathrm{f}}$ & $0.334^{\mathrm{f}}$ & $0.427^{g}$ & $0.616^{\mathrm{a}}$ & $0.519^{\mathrm{a}}$ & $0.118^{\mathrm{de}}$ & $1.744^{\mathrm{d}}$ & $0.272^{\mathrm{d}}$ \\
\hline C8 & $1.369^{\mathrm{b}}$ & $1.885^{\mathrm{a}}$ & $1.373^{\mathrm{b}}$ & $1.011^{\mathrm{b}}$ & $0.487^{\mathrm{ef}}$ & $0.248^{\mathrm{d}}$ & $0.062^{\mathrm{f}}$ & $0.156^{\mathrm{c}}$ & $1.489^{\mathrm{e}}$ & $0.549^{c}$ \\
\hline C9 & $1.002^{\mathrm{h}}$ & $0.502^{\mathrm{h}}$ & $0.192^{\mathrm{g}}$ & $0.095^{\mathrm{i}}$ & $0.589 b^{\mathrm{c}}$ & $0.114^{\text {gh }}$ & $0.106^{\mathrm{d}}$ & $0.127^{\mathrm{d}}$ & $1.321^{\mathrm{f}}$ & $0.093^{\mathrm{g}}$ \\
\hline C10 & $1.343^{b}$ & $0.900^{\mathrm{e}}$ & $0.516^{\mathrm{e}}$ & $0.238^{g}$ & $0.525^{\mathrm{de}}$ & $0.407^{\mathrm{c}}$ & $0.212^{\mathrm{b}}$ & $0.106^{\mathrm{ef}}$ & $2.056^{\mathrm{b}}$ & $0.181^{\mathrm{e}}$ \\
\hline C11 & $1.286^{\mathrm{bc}}$ & $1.814^{\mathrm{ab}}$ & $0.826^{\mathrm{d}}$ & $0.778^{\mathrm{d}}$ & $0.645^{a}$ & $0.105^{\text {gh }}$ & $0.071^{\mathrm{ef}}$ & $0.09^{\mathrm{fg}}$ & $0.786^{\mathrm{h}}$ & $0.091^{\mathrm{g}}$ \\
\hline C12 & $1.240^{\text {cde }}$ & $1.784^{\mathrm{b}}$ & $1.460^{\mathrm{a}}$ & $1.162^{\mathrm{a}}$ & $0.401^{\mathrm{g}}$ & $0.15^{\mathrm{f}}$ & $0.059^{\mathrm{f}}$ & $0.0182^{\mathrm{i}}$ & $1.514^{\mathrm{e}}$ & $0.104^{\mathrm{g}}$ \\
\hline
\end{tabular}

Note: The same letter in the superscripts indicates no significant difference between the observation

Table 5: Percentage inhibition of Maize seed-borne pathogen Macrophomina phaseolina and Fusarium oxysporum by bacterial seed endophytes

\begin{tabular}{|c|c|c|}
\hline \multirow{2}{*}{ Isolates } & \multicolumn{2}{|c|}{ Percent inhibition of Fungal pathogen (\%) } \\
\cline { 2 - 3 } & Macrophomina phaseolina & \multicolumn{2}{c|}{ Fusarium oxysporum } \\
\hline C1 & 0 & 24.64 \\
\hline C2 & 0 & 38.84 \\
\hline C3 & 0 & 31.88 \\
\hline C4 & 0 & 2.9 \\
\hline C5 & 0 & 0 \\
\hline C6 & 0 & 23.19 \\
\hline C7 & 0 & 0.7 \\
\hline C8 & 0 & 0 \\
\hline C9 & 0 & 2.9 \\
\hline C10 & 0 & 0 \\
\hline C11 & 14.86 & 23.19 \\
\hline
\end{tabular}




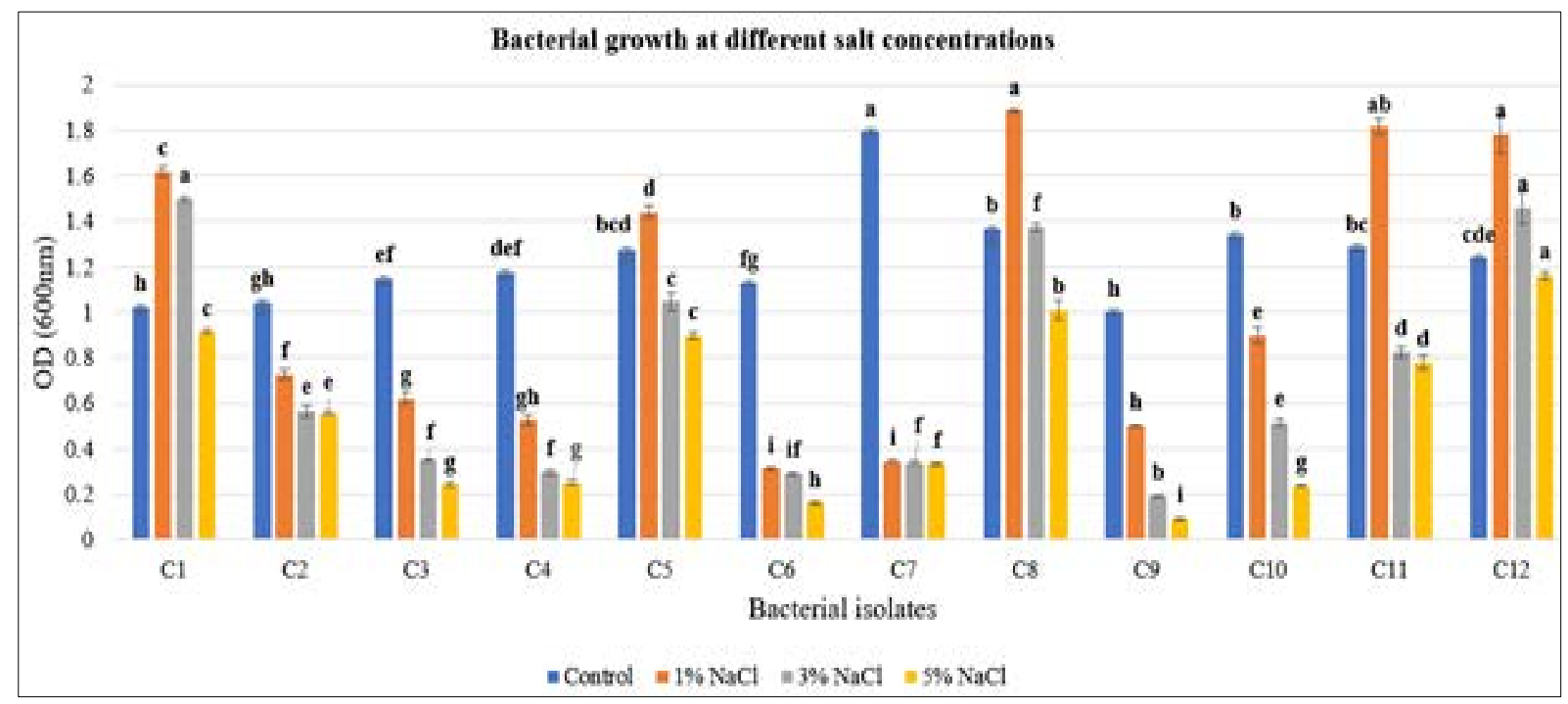

Fig 1: Salt tolerance by seed bacterial endophytes

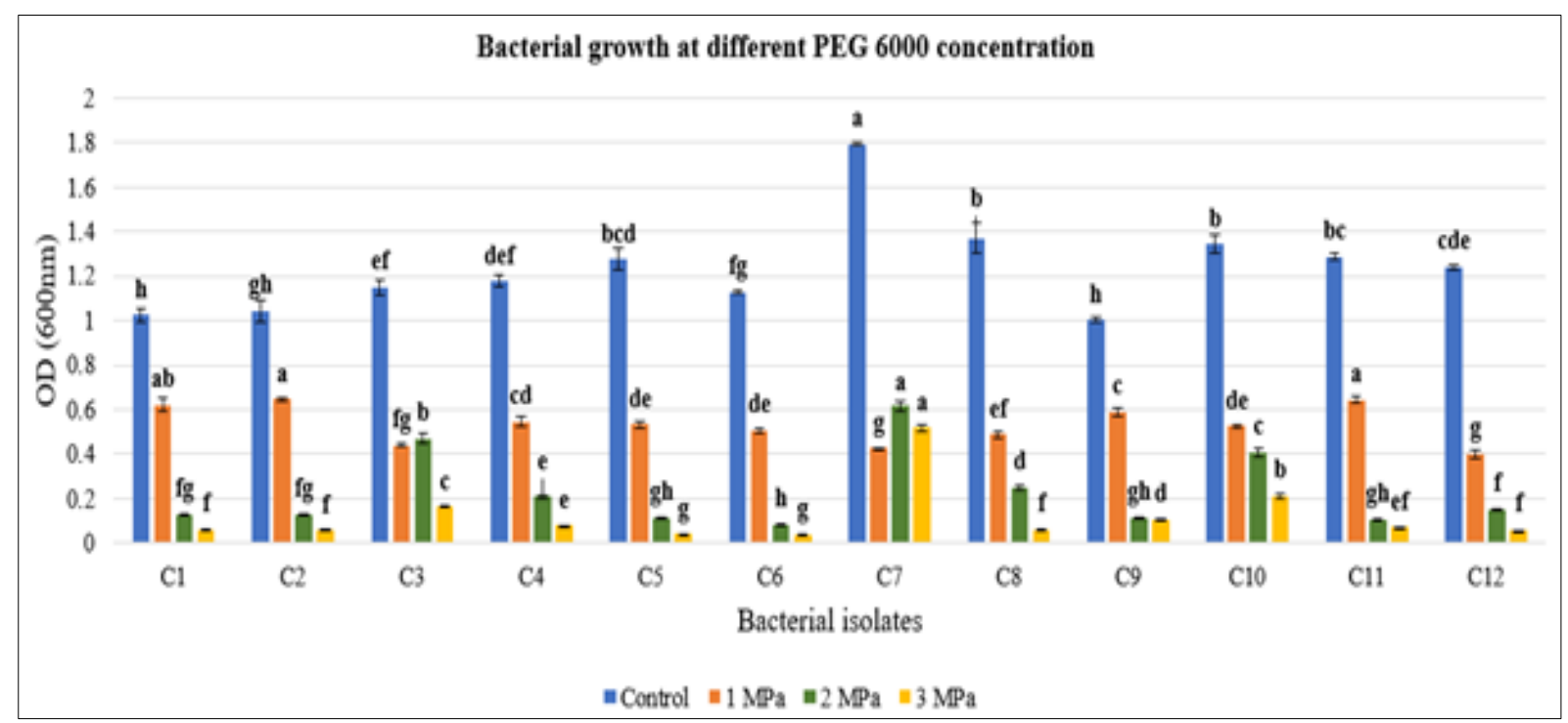

Fig 2: Moisture stress tolerance by seed bacterial endophytes

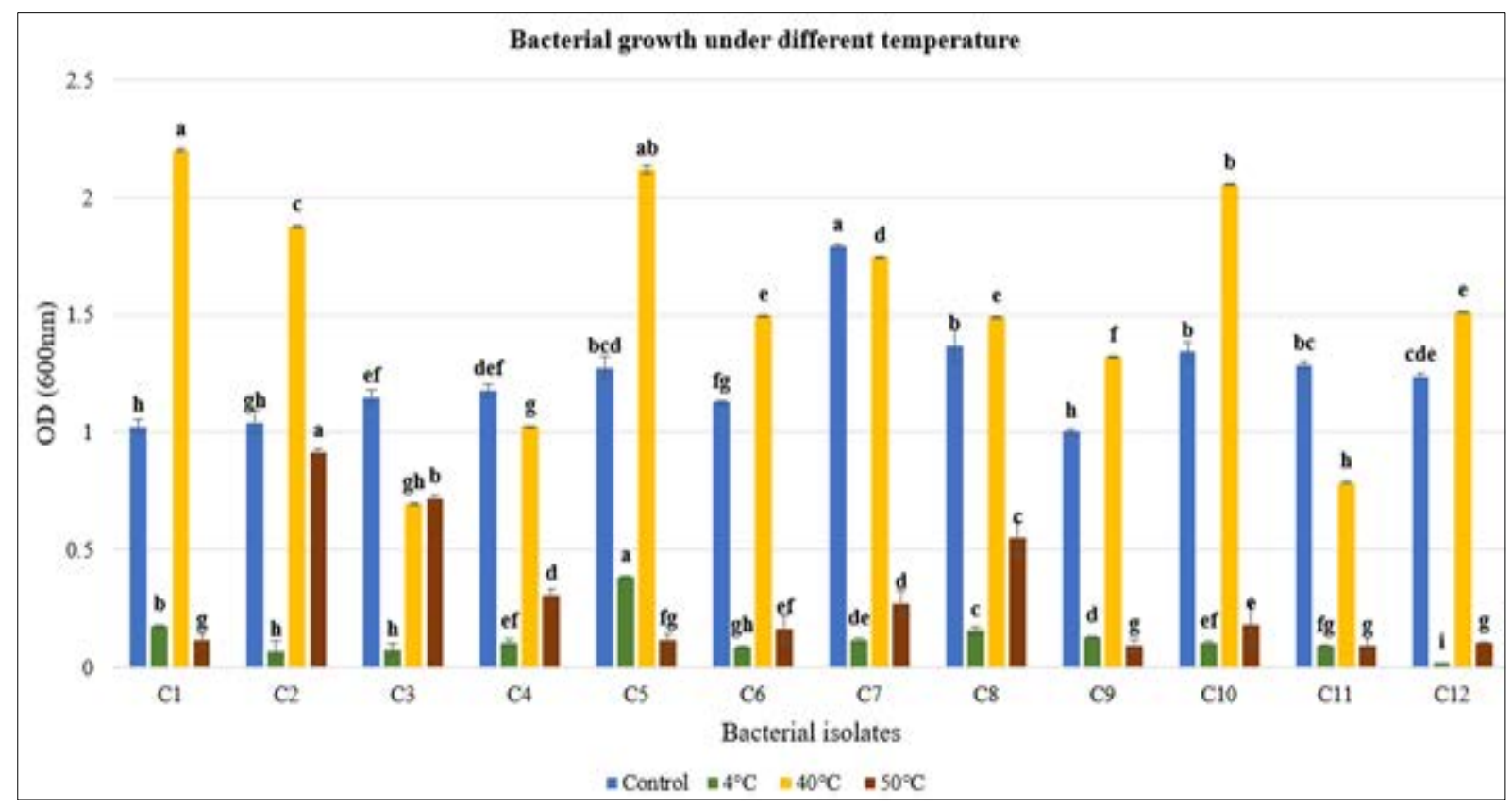

Fig 3: Temperature tolerance by seed bacterial endophytes 

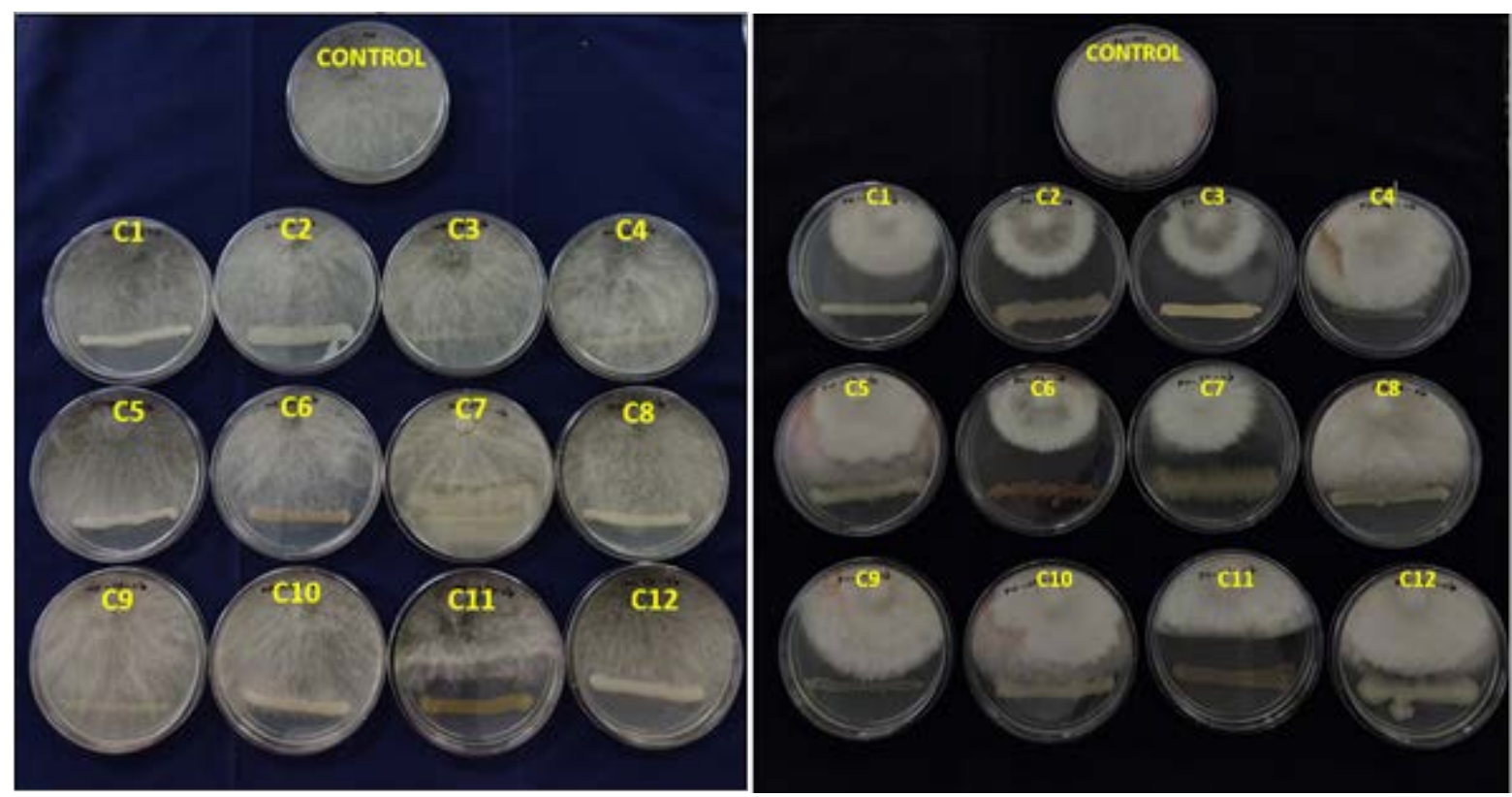

Fig 4: In vitro antagonistic activity of bacterial isolates against fungal pathogen Macrophomina phaseolina and Fusarium oxysporum

\section{Conclusion}

From the present study, it is confirmed that the seedassociated bacterial endophytes of maize successfully tolerate environmental stresses. The results suggest that the isolates C3, C7, C11, and C12 could be utilized as consortia to mitigate the stress condition and these isolates could assist the crop in addressing the problem of biotic and abiotic stresses and act as an effective strategy for improving the sustainability in agriculture. The microorganisms from the seed source favor the plants for the effective colonization of beneficial microorganisms in the seedling establishment stage and assisting plant growth.

\section{Authors Contribution}

The authors of the manuscript have an equal contribution

\section{Acknowledgements}

We thankful to the Department of Millets \& Department of Agricultural Microbiology, Tamil Nadu Agricultural University for providing the seed sources and laboratory facilities to conduct this research.

\section{Conflict of interest}

The authors declare that there is no conflict of interest.

\section{References}

1. Yang J, Kloepper JW, Ryu CM. Rhizosphere bacteria help plants tolerate abiotic stress. Trends in plant science 2009;14(1):1-4.

2. Khalaf EM, Raizada MN. Taxonomic and functional diversity of cultured seed-associated microbes of the cucurbit family. BMC microbiology 2016;16(1):1-6.

3. Sandhu KS, Singh N, Malhi NS. Some properties of corn grains and their flours I: Physicochemical, functional and chapati-making properties of flours. Food Chemistry 2007;101(3):938-46.

4. El Attar I, Taha K, El Bekkay B, El Khadir M, Alami IT, Aurag J. Screening of stress tolerant bacterial strains possessing interesting multi-plant growth promoting traits isolated from root nodules of Phaseolus vulgaris L. Biocatalysis and Agricultural Biotechnology 2019;20:101225.
5. Abiola C, Oyetayo VO. Isolation and Biochemical Characterization of Microorganisms associated with the Fermentation of Kersting's groundnut (Macrotyloma geocarpum). Res J Microbiol 2016;11(2-3):47-55.

6. Cheesbrough M. District laboratory practice in tropical countries, part 2. Cambridge University press 2005.

7. Olutiola PO, Famurewa O, Sonntag HG. An introduction to General Microbiology: A practical approach. ( $2^{\text {nd }}$ edn). Ikeja, Lagos, Nigeria: Bolabay Publications 2000.

8. Finegold S, Martin W. Baily and Scott's Diagnostic Microbiology. St. Louis C.

9. Fawole MO, Oso BA. Characterization of bacteria: Laboratory manual of microbiology. Spectrum Book Ltd., Ibadan, Nigeria 2004, 24.

10. Gupta P, Samant K, Sahu A. Isolation of cellulosedegrading bacteria and determination of their cellulolytic potential. International journal of microbiology 2012.

11. Patil NP, Chaudhari BL. Production and purification of pectinase by soil isolate Penicillium sp and search for better agro-residue for its SSF. Recent Research in Science and Technology 2010;2(7):36-42.

12. Budi SW, van Tuinen D, Arnould C, Dumas-Gaudot E, Gianinazzi-Pearson V, Gianinazzi S. Hydrolytic enzyme activity of Paenibacillus sp. strain B2 and effects of the antagonistic bacterium on cell integrity of two soil-borne pathogenic fungi. Applied Soil Ecology 2000;15(2):1919.

13. Lim HS, Kim YS, Kim SD. Pseudomonas stutzeri YPL-1 genetic transformation and antifungal mechanism against Fusarium solani, an agent of plant root rot. Applied and Environmental Microbiology 1991;57(2):510-6.

14. Kumar DA, Sabarinathan KG, Kannan R, Balachandar D, Gomathy M. Isolation and Characterization of Drought Tolerant Bacteria from Rice Phyllosphere. Int. J Curr. Microbiol. Appl. Sci 2019;8:2655-64.

15. Bodhankar S, Grover M, Hemanth S, Reddy G, Rasul S, Yadav SK et al. Maize seed endophytic bacteria: dominance of antagonistic, lytic enzyme-producing Bacillus spp. 3 Biotech 2017;7(4):1-3.

16. Sturz AV, Christie BR, Nowak J. Bacterial endophytes: potential role in developing sustainable systems of crop production. Critical reviews in plant sciences. 2000 Jan 
$1 ; 19(1): 1-30$.

17. Pal KK, Dey R, Sherathia DN, Mangalassery S, Kumar A, Rupapara RB, Mandaliya M, Rawal P, Bhadania RA, Thomas M, Patel MB. Alleviation of Salinity Stress in Peanut by Application of Endophytic Bacteria. Frontiers in Microbiology. 2021 Apr 14;12:791

18. Jeong S, Kim TM, Choi B, Kim Y, Kim E. Invasive Lactuca serriola seeds contain endophytic bacteria that contribute to drought tolerance. Scientific reports. 2021 Jun 25;11(1):1-2.

19. Rothschild LJ, Mancinelli RL. Life in extreme environments. Nature. 2001 Feb;409(6823):1092-101. 